\title{
ЭФФЕКТИВНОСТЬ БЮДЖЕТНОЙ ПОЛИТИКИ В САУДОВСКОЙ АРАВИИ
}

\author{
(c) 2021 Сафиуллин Ленар Наилевич \\ доктор экономических наук, профессор \\ Казанский (Приволжский) федеральный университет, Россия, Казань \\ E-mail: lenar_s@mail.ru \\ (c) 2021 Абдулла Али Аль-Масаид \\ соискатель \\ Казанский (Приволжский) федеральный университет, Россия, Казань \\ E-mail: almasaeed.abdullah@yahoo.com.ph
}

Статья содержит анализ бюджетной политики Саудовской Аравии. Данное исследование актуально, в том числе для российских исследователей, поскольку Саудовская Аравия представляет собой модель государства, которое зависит, прежде всего, от добывающей промышленности, в частности, экономическое благополучие во многом складывается из экспорта нефти. Важно понимать, насколько власть способна регулировать экономическую отрасль в условиях колебаний цен на мировом рынке нефти. В статье проанализированы доходы Саудовской Аравии, а также их структура в разрезе добывающей и обрабатывающей промышленности. Также проанализирована взаимосвязь сырьевого сектора и темпов роста ВВП. По итогам исследования сделан вывод, что государство трудно адаптируется к ситуации низких цен на нефть. Обрабатывающая промышленность развита слабо, поэтому быстро преодолеть период экономических спадов не получается. Исходя из этого, государство в последние годы предпринимает попытки перехода к инновационной экономике. Авторами выработаны рекомендации для достижения экономического роста в стране, в частности, предлагается диверсифицировать источники доходов и создать резервы, которые не основаны на нефтяных ресурсах. Также отмечено, что необходимо усиление роли частного сектора в экономике.

Ключевые слова: бюджетная политика, экономический рост, ВВП добывающая промышленность, нефтяные доходы, инвестиции, Саудовская Аравия.

Бюджет Саудовской Аравии складывается в основном за счет нефти. Страна имеет самые большие запасы сырой нефти в мире и является одним из крупнейших ее производителей и экспортеров. Однако получаемые государством нефтяные доходы уязвимы, так как зависят от колебаний мировых цен на нефть. В таблице (таблица 1) приведены доходы, полученные государством в 2000-2016 гг.

Отметим, что в 2000 г. Саудовская Аравия достигла профицита в размере 6203 млн. долл., в 2001 и 2002 гг.- дефицита в 7195 млн. долл. и 5467 млн.долл., соответственно. Затем в течение шести лет бюджет страны сохранял профицит (в 2006 г. -74763 млн. долл.), в 2009 г.- снова отмечается дефицит в размере 23101 млн. долл. (в результате воздействия мирового финансового кризиса, снизившего спрос на нефть). В 20132014 гг. профицит сохранялся, но в 2015 г. был зафиксирован самый высокий уровень дефицита в течение исследуемого периода - 89981 млн. долл., что было связано со снижением нефтяных доходов; в 2016 г. дефицит бюджета сократился до 83734 млн. долл.

На рисунке 1 показана динамика государственных доходов в Саудовской Аравии в 20002016 гг. (с учетом данных таблицы 1).

Данные, приведенные в табл. 2, отражают увеличение доли нефтяных доходов в государственных: так, в 2000 г. этот показатель достиг 85,84\% (57177 млн. долл.), затем в 2002 г. он снизился до 77,98\% (44292 млн. долл.), в 2006 и 2005 гг. наблюдается увеличение до 89\%; в 2010, 2011 и 2012 гг. показатель вырос вновь, превысив 90\%, что было связано с повышением цен на нефть. Однако в 2016 г., после падения цен, значения показателя опустились до 60,56\%.

При этом доля ненефтяных доходов была ниже требуемого уровня: в 2000 г. - 14,16\% (9432 млн. долл.), в 2011 г. зафиксирован самый низкий уровень - 7,43\% (22 139 млн. долл.). В 2015 и 2016 гг. вклад ненефтяных доходов в общие доходы увеличился до $27,35 \%$ и $39,44 \%$ соответственно (44821 и 57951 млн. долл.). Этому способствовали падение цен на нефть и введение налоговых льгот, а также многочисленные 
Таблица 1. Доходы бюджета Саудовской Аравии за 2000-2016 гг., млн. долл.

\begin{tabular}{|c|c|c|c|c|}
\hline Год & $\begin{array}{l}\text { Общие } \\
\text { доходы }\end{array}$ & $\begin{array}{c}\text { Доходы } \\
\text { от экспорта нефти }\end{array}$ & $\begin{array}{c}\text { Ненефтяные } \\
\text { доходы }\end{array}$ & $\begin{array}{c}\text { Сальдо } \\
\text { бюджета }\end{array}$ \\
\hline 2000 & 66609 & 57177 & 9432 & 6203 \\
\hline 2001 & 60842 & 49044 & 11798 & -7195 \\
\hline 2002 & 56800 & 44292 & 12508 & -5467 \\
\hline 2003 & 78133 & 61606 & 16527 & 9600 \\
\hline 2004 & 104611 & 87998 & 16613 & 28558 \\
\hline 2005 & 150489 & 134537 & 15952 & 58096 \\
\hline 2006 & 179649 & 161199 & 18450 & 74763 \\
\hline 2007 & 171413 & 149917 & 21496 & 47080 \\
\hline 2008 & 293598 & 262241 & 31357 & 154913 \\
\hline 2009 & 135948 & 115841 & 20107 & -23101 \\
\hline 2010 & 197764 & 178719 & 19045 & 23395 \\
\hline 2011 & 297961 & 275822 & 22139 & 77508 \\
\hline 2012 & 332395 & 305271 & 27124 & 99514 \\
\hline 2013 & 307342 & 276023 & 31319 & 58782 \\
\hline 2014 & 277371 & 243559 & 33812 & 18123 \\
\hline 2015 & 163876 & 119055 & 44821 & -89981 \\
\hline 2016 & 146933 & 88982 & 57951 & -83734 \\
\hline
\end{tabular}

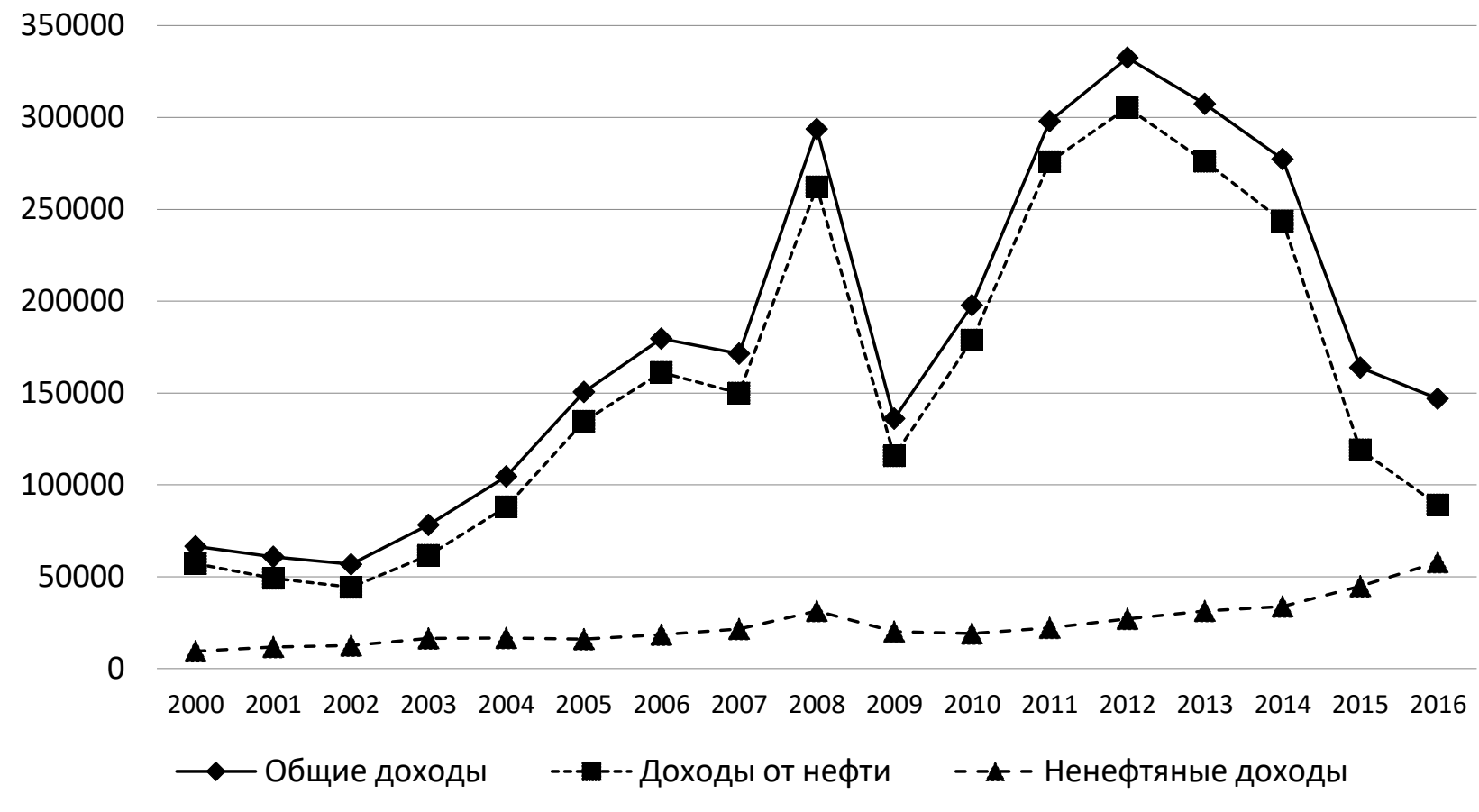

Puc. 1. Государственные доходы в Саудовской Аравии (2000-2016 гг.) 
попытки реформировать финансовую систему Саудовской Аравии, рационализировать расходы. Введение множества законов по борьбе с коррупцией дало возможность вернуть денежные средства, нелегально выведенные из бюджета, в экономику страны. Можно говорить о том, что арабские нефтяные государства в целом и Саудовская Аравия в частности стремятся диверсифицировать свои ресурсы, чтобы укрепить свои экономики и быть готовыми к потрясениям, вызванным изменениями мировых цен на нефть [6].

Для того чтобы оценить развитие темпов экономического роста в Саудовской Аравии, рассмотрим два наиболее важных показателя для его измерения - темпы роста ВВП и средний ВВП на душу населения за отдельные годы исследуемого периода (таблица 2).

На основе данных можно говорить о том, что темпы роста ВВП нестабильны и время от времени изменяются в результате колебаний цен на нефть. Причем на темпы роста повлиял мировой финансовый кризис (в 2008 г. рост достиг отметки -2,1), что свидетельствует об открытости Саудовской Аравии для мировой экономики.

Также отметим, что темпы экономического роста снизились с 5,6\% в 2000 г. до 2,8\% в 2006 г., а затем до 2,7\% в 2012 г., так как страна испытала на себе последствия обвала мирового рынка. Изза падения мировых цен на нефть в 2016 г. показатели снизились еще больше $-1,7 \%$.

Что касается изменения уровня ВВП на душу населения, то рост доходов Саудовской Аравии после фиксации цен на нефть показал положительную динамику. Особенно после 2005 г., превысив барьер в 15000 долл. и достигнув примерно 26000 долл. Это было связано с увеличением стоимости ВВП, получаемого от экспорта саудовской нефти: в период с 2000 по 2013 г. этот показатель вырос почти в три раза.

Исходя из структуры ВВВ по видам экономической деятельности нефтяной сектор, естественно, имеет наибольшую долю. В таблице 3 показаны наиболее важные сферы экономики Саудовской Аравии, влияющие на уровень ВВП.

Таблица 2. Темпы экономического роста в Саудовской Аравии (2000-2016 гг.)

\begin{tabular}{|c|c|c|}
\hline Год & $\begin{array}{c}\text { Темпы экономического роста } \\
\text { ВВП,\% }\end{array}$ & вВП на душу населения, долл. \\
\hline 2000 & 5,6 & 9127,0 \\
\hline 2001 & 1 & 8983,1 \\
\hline 2002 & 1,8 & 9988,4 \\
\hline 2003 & 6,4 & 11871,5 \\
\hline 2004 & 5,3 & 12235,8 \\
\hline 2005 & 5,6 & 13739,8 \\
\hline 2006 & 2,8 & 15334,7 \\
\hline 2007 & 1,8 & 16472,2 \\
\hline 2008 & 6,2 & 20037,8 \\
\hline 2009 & $-2,1$ & 16094,3 \\
\hline 2010 & 5 & 19259,6 \\
\hline 2011 & 10 & 23770,7 \\
\hline 2012 & 5,4 & 25303,1 \\
\hline 2013 & 2,7 & 24934,4 \\
\hline 2014 & 3,7 & 24575,4 \\
\hline 2015 & 4,1 & 20732,9 \\
\hline 2016 & 1,7 & 19982,1 \\
\hline
\end{tabular}

Таблица 3. Отраслевое распределение ВВП Саудовской Аравии со средним годовым показателем за 2000-2016 гг.,\%

\begin{tabular}{|c|c|c|c|c|c|c|}
\hline Сектор & Нефть & $\begin{array}{c}\text { Обрабатыва- } \\
\text { ющая про- } \\
\text { мышленность }\end{array}$ & $\begin{array}{c}\text { Сельское } \\
\text { хозяйство }\end{array}$ & $\begin{array}{c}\text { Строитель- } \\
\text { ство }\end{array}$ & Услуги & Всего \\
\hline Вклад, \% & 40,15 & 10,43 & 3,15 & 11 & 35,26 & 100 \\
\hline
\end{tabular}


Таким образом, исходя из исследования, в 2016 г. можно сделать следующие выводы:

- государственные расходы в Саудовской Аравии неуклонно растут, что связано с расширением сфер государственного влияния, увеличением социальных, медицинских и образовательных потребностей, а также увеличением расходов на оборону и безопасность;

- нефтяные доходы составляют значительную долю доходов Саудовской Аравии, следовательно, государственные расходы полностью зависят от нефтяного сектора, а экономика в целом подчиняется законам развитых капиталистических стран, поскольку большая часть денежных средств поступает из внешнего мира. Это делает экономику государства более уязвимой к экономическим кризисам, происходящим в развитых странах, так как их последствия препятствуют росту и целенаправленному экономическому и социальному развитию;

- темпы экономического роста колеблются, однако самая большая проблема заключается в том, что ВВП в значительной степени зависит от нефти. Сложившаяся экономическая модель дестабилизирует экономический рост и делает его уязвимым для любых внешних событий например, негативные последствия для экономики Саудовской Аравии имели глобальный кризис 2008 г., снижение мировых цен на нефть

В итоге Саудовской Аравии следует обратить внимание на следующие аспекты:

- правительству следует диверсифицировать источники доходов и создать резервы, которые не основаны на нефтяных ресурсах в качестве единственного источника. Для этого необходимо опираться на финансовые потоки, поступающие из несырьевых секторов, обеспечивая тем самым долгосрочное финансирование. Таким образом, можно добиться снижения рисков, связанных с использованием одного товара в качестве источника дохода, особенно с учетом нестабильности цен на нефть;

- государство должно проанализировать затраты и доходы, а также повысить качество технических исследований по проектам и активизировать работу технических и финансовых надзорных органов;

- Саудовской Аравии необходимо усиление роли частного сектора, расширение сфер его деятельности;

- власть должна акцентировать внимание на исследованиях и разработках (НИОКР), поскольку они оказывают положительное воздействие на долгосрочный экономический рост. Именно экспорт наукоемкой продукции дает положительный долгосрочный эффект.

\section{Библиографический список}

1. Saleh F.A., Al-Otaibi M.M., Al-Zoreky N.S. Quality Assessment of Frying Oil from some Restaurants in Al Ahsa, Saudi Arabia // Scientific Journal of King Faisal University. - 2021. - Volume 22, Issue 1. - Pp. 42-47.

2. Karanfil F., Pierru A. The opportunity cost of domestic oil consumption for an oil exporter: Illustration for Saudi Arabia // Energy Economics. - 2021. - Volume 96. - Pp. 460-485.

3. Alharbi A. Economic effects of low oil prices in Saudi Arabia // International Journal of Information Technology (Singapore). - 2021. - Volume 13, Issue 1.- Pp. 195-200.

4. Siregar R., Goo S. Effectiveness and commitment to inflation targeting policy: evidence from Indonesia and Thailand // Journal of Asia Economics. - 2010. - Volume 21. - Pp. 113-128.

5. Sommer M. Labour agenda for change // International Journal of Labour Research. - 2011.- Volume 3.- Issue 1.- Pp. $15-20$.

6. Rahim S.A., Batahir S. The Effectiveness of Financial Policy in Algeria: An Analytical Approach // Journal of Development and Economic Policies. - 2010.- Volume 12, Issue 1.- Pp. 37-39.

7. Руденко Л.Н. Экономика Саудовской Аравии в условиях низких нефтяных цен // Российский внешнеэкономический вестник.-2020.- № 5.- С. 39-47.

8. Бобылев Ю.Н., Каукин А. С., Миллер Е. М. Текущее состояние и перспективы на мировом рынке нефти // Экономическое развитие России. - 2020.- № 5.- С. 50-57.

9. Фахрутдинова Е.В., РоднянскийД.В. Анализ энергетических кластеров и их влияния на социальноэкономическое развитие России// Экономические науки. 2016. № 142. С.26-29.

10. Фахрутдинова Е.В., Колесникова Ю. С. НR-бренд, бренд и репутация компании как объекты нематериальной собственности// Креативная экономика. 2013. № 2 (74). С.69-76. 